\title{
DOCHODZENIE ROSZCZEŃ Z TYTUŁU SZKÓD SPOWODOWANYCH RUCHEM ZAKŁADU GÓRNICZEGO
}

\section{VINDICATION OF CLAIMS FOR DAMAGES CAUSED BY MINING PLANT OPERATIONS}

\author{
http://dx.doi.org/10.12775/PPOS.2015.040
}

\section{STRESZCZENIE}

Artykuł zawiera rozważania dotyczące szkód spowodowanych ruchem zakładu górniczego na terenie Rzeczpospolitej Polskiej. Autor opisuje problem szkód górniczych, jego źródło oraz wskazuje obszar występowania. Następnie szczegółowo omawia regulacje dotyczące dochodzenia roszczeń spowodowanych ruchem zakładu górniczego zawarte przede wszystkim w ustawie z dnia 9 czerwca 2011 roku Prawo geologiczne i górnicze ${ }^{1}$ oraz Kodeksie cywilnym ${ }^{2}$. Nadto podejmuje

Student IV roku prawa na Uniwersytecie Śląskim w Katowicach.

1 T. j. Dz.U. z 2015 r., poz. 196 (dalej cyt.: u.p.g.g.).

2 T. j. Dz.U. z 2014 r., poz. 121 ze zm. (dalej cyt.: k.c.). 
się szczegółowej analizy najważniejszych przepisów w przytoczonych aktach prawnych, dokonując ich oceny.

Autor opisuje także przebieg pozasądowego postępowania ugodowego pomiędzy poszkodowanym a przedsiębiorcą prowadzącym ruch zakładu górniczego ${ }^{3}$.

\title{
Słowa kluczowe
}

Prawo geologiczne i górnicze; zakład górniczy; szkody górnicze Prawo geologiczne i górnicze; naprawienie szkody górniczej.

\begin{abstract}
The article contains a reflection considering damages caused by mining plant operations in Poland. The author describes the problem of mining damages, its roots and indicates the areas of the problem. Subsequently, he depicts in detail regulations referring to the vindication of claims for damages caused by mining plant operations. The aforementioned rules are primarily regulated in the Act of 9 June 2011 on Geological and Mining Law and in the Civil Code. Moreover, he conducts an accurate analysis and assessment of the most important regulations of the above-mentioned acts. The author also describes out-of-court settlement proceedings between an injured party and the mining plant.
\end{abstract}

\section{Keywords}

Geological and mining law; mining plant; mining damage; damages.

3 Zgodnie z art. 6 ust. 1 pkt 18 zakładem górniczym jest „wyodrębniony technicznie i organizacyjnie zespół środków służących bezpośrednio do wykonywania działalności regulowanej ustawą w zakresie wydobywania kopalin ze złóż, a w podziemnych zakładach górniczych wydobywających węgiel kamienny wraz z pozostającym w związku technologicznym z wydobyciem kopaliny przygotowaniem wydobytej kopaliny do sprzedaży, podziemnego bezzbiornikowego magazynowania substancji, podziemnego składowania odpadów albo podziemnego składowania dwutlenku węgla, w tym wyrobiska górnicze, obiekty budowlane, urządzenia oraz instalacje". 


\section{UWAGI WSTĘPNE}

Szkody spowodowane ruchem zakładów górniczych, z uwagi na skalę problemu, są ważkim tematem przede wszystkim w południowej części Polski. Głównym obszarem, którego dotyczy przedmiotowy problem jest Górny Śląsk, gdzie funkcjonuje obecnie ponad 20 kopalń samego tylko węgla kamiennego. Ze względu na ilość spraw sądowych dotyczących szkód górniczych w Sądzie Wojewódzkim w Katowicach (a od 1 stycznia 1999 roku w Sądzie Okręgowym) w latach 1994-2012 sprawy z zakresu geologii i górnictwa należały do właściwości odrębnego od wydziałów cywilnych sądu, XX Wydziału Spraw Geologicznych i Górniczych ${ }^{4}$. Mimo zauważalnego spadku wydobycia ${ }^{5}$ na skutek procesów restrukturyzacji, Polska jest wciąż największym producentem węgla kamiennego w Unii Europejskiej ${ }^{6}$. Innymi regionami dotkniętymi problemem szkód górniczych jest m.in. Małopolska czy też Dolny Śląsk.

Umiejscowienie zakładu górniczego warunkowane jest oczywiście pokładami surowca naturalnego, którego wydobycie stanowi przedmiot działalności tegoż zakładu. Obecnie obowiązująca u.p.g.g. definiuje złoże kopaliny ,jako naturalne nagromadzenie minerałów, skał oraz innych substancji, których wydobywanie może przynieść korzyść gospodarczą". W przytoczonej definicji, ze względu na omawiany problem, szczególną uwagę należy zwrócić na wyrażenie „może przynieść korzyść gospodarczą". Bezspornym jest fakt, że to właśnie ową korzyścią gospodarczą kierują się przedsiębiorcy prowadzący ruch zakładu górniczego. Wskazuje na to również treść art. 2 ustawy o swobodzie działalności gospodarczej z dnia 2 lipca 2004 roku$^{7}$,

4 T. j. Dz. Urz. Ministra Sprawiedliwości z 1994 roku, nr 3, poz. 20 Zarządzenie Ministra Sprawiedliwości zmieniające zarządzenie w sprawie utworzenia wydziałów w niektórych sądach wojewódzkich, oznaczenia nazw wydziałów i ustalenia zakresu spraw przekazanych tym wydziałom oraz w sprawie określenia wydziału rozpoznającego w II instancji sprawy nieletnich, § 1 pkt f.

5 GUS: Rocznik Statystyczny Rzeczpospolitej Polskiej 2014, s. 512.

6 GUS: Rocznik Statystki Międzynarodowej 2012, s. 396.

7 T. j. Dz.U. z 2015 roku, poz. 584 ze zm. 
zgodnie z którym działalnością gospodarczą jest m.in.: poszukiwanie, rozpoznawanie i wydobywanie kopalin ze złóż o charakterze zarobkowym, ciągłym i zorganizowanym. Poszukiwanie, rozpoznanie i wydobywanie kopalin ma jednak częstokroć negatywne skutki dla środowiska i obiektów otaczających „obszar górniczy", które ujawniają się w postaci tzw. szkód górniczych. Ustawa Prawo geologiczne i górnicze w art. 6 pkt 15 wprowadza definicję legalną przestrzeni objętej przewidywanymi szkodliwymi wpływami robót górniczych zakładu górniczego, nazywając taką przestrzeń „terenami górniczymi”. Należy więc wskazać, że wyrażenie „może przynieść korzyść gospodarczą” zostało użyte celowo, z uwagi na możliwość osiągnięcia ujemnego bilansu pomiędzy zyskami zakładu górniczego z wydobytych kopalin, a kosztami ich wydobycia i powstałymi szkodami na terenach górniczych.

Szkody górnicze od ponad 20 lat nie posiadają definicji legalnej na gruncie obowiązujących przepisów. Pojęcie to zostało wprowadzone nieobowiązującym już dekretem Prawo górnicze z dnia 6 maja 1953 roku9 ${ }^{9}$. Wskazany akt prawny definiuje szkodę górniczą jako szkodę powstałą wskutek robót górniczych w nieruchomości, budynku lub innej części składowej nieruchomości, bez względu na to, czy szkodę można było przewidzieć oraz czy ktokolwiek ponosi winę uszkodzenia. Przytoczona definicja tak mocno zakorzeniła się w języku potocznym, że używa się jej do dzisiaj jako synonimu szkody wyrządzonej ruchem zakładu górniczego ${ }^{10}$.

8 Pojęcie to zostało zdefiniowane w art. 6 pkt 5 u.p.g.g. jako „przestrzeń, w granicach której przedsiębiorca jest uprawniony do wydobywania kopaliny, podziemnego bezzbiornikowego magazynowania substancji, podziemnego składowania odpadów, podziemnego składowania dwutlenku węgla oraz prowadzenia robót górniczych niezbędnych do wykonywania koncesji”.

9 T. j. Dz.U. z 1953 roku, Nr 29, poz. 113, uchylony 1 września 1994 roku.

10 Szerzej na temat regulacji zawartych w dekrecie Prawo górnicze z dnia 6 maja 1953 roku: K. Lipińska, Tryb dochodzenia roszczeń z tytułu tzw. Szkód górniczych, w: Prawna regulacja geologii i górnictwa w Polsce, Czechach i na Stowacji. Wybrane zagadnienia, red. G. Dobrowolski, G. Radecki, Katowice 2014, s. 172 i nast. 


\section{POJĘCIE SZKODY ORAZ RUCHU ZAK£ADU GÓRNICZEGO I JEGO SKUTKI}

Odpowiedzialność za szkody wyrządzone ruchem zakładu górniczego oraz procedura dochodzenia roszczeń z tytułu tych szkód została uregulowana przez ustawodawcę w u.p.g.g. oraz k.c. Zgodnie z art. 145 u.p.g.g. „do naprawiania szkód, o których mowa w art. 144 ust. 1 i $2^{11}$, stosuje się przepisy Kodeksu cywilnego". Nie budzi zatem wątpliwości fakt, że odpowiedzialność ta ma charakter cywilnoprawny.

$\mathrm{Z}$ uwagi na dalsze rozważania fundamentalne znaczenie przypisać należy pojęciu szkody, którym posługuje się ustawodawca cywilny, nie definiując go jednak. Zgodnie ze stanowiskiem doktryny pojęcie to oznacza uszczerbek o charakterze majątkowym, jak i niemajątkowym, który dotyka poszkodowanego wbrew jego woli. Uszczerbek ten może przybrać postać dwojaką - straty, którą poszkodowany poniósł oraz korzyści, które mógłby osiągnąć, gdyby szkoda nie została mu wyrządzo$n^{12}$. Należy wskazać, że przytoczona definicja zachowuje swoją ważność również na gruncie u.p.g.g. ${ }^{13}$

Jak już zostało zasygnalizowane wyżej, ustawodawca nie posługuje się obecnie definicją legalną szkody wyrządzonej ruchem zakładu górniczego, co więcej, nie definiuje również pojęcia ruchu zakładu górniczego, które wprowadził na gruncie poprzedniej ustawy z dnia 4 lutego 1994 roku Prawo geologiczne

11 Artykuł 144 ust. 1 u.p.g.g. odnosi się do właściciela, który nie może sprzeciwić się zagrożeniom spowodowanym ruchem zakładu górniczego, który jest prowadzony zgodnie $\mathrm{z}$ ustawą. Może on jednak żądać naprawienia wyrządzonej tym ruchem szkody na zasadach określonych ustawą. Artykuł 144 ust. 2 u.p.g.g. wskazuje, że regulacja wskazana w ust. 1 stosuje się odpowiednio do innych podmiotów, których prawa są zagrożone ruchem zakładu górniczego.

12 W. Czachórski, A. Brzozowski, M. Safjan, E. Skowrońska-Bocian, Zobowiązania. Zarys wykładu, Warszawa 2009, s. 88.

13 Wskazuje na to przede wszystkim brak odmiennego uregulowania w samej u.p.g.g. oraz przytoczone wyżej odwołanie w art. 145 u.p.g.g. do przepisów k.c. 
i górnicze ${ }^{14}$. Przytaczanie owej definicji jest zbędne w kontekście dalszych rozważań, należy jedynie podkreślić, że w doktrynie budziła ona spore wątpliwości ${ }^{15}$.

\section{RESTYTUCYJNA I PREWENCYJNA FUNKCJA ROSZCZEŃ}

Przechodząc do analizy funkcji, jakie spełniają roszczenia przysługujące podmiotom legitymowanym czynnie, należy zwrócić szczególną uwagę na art. 144, 150 i 152 u.p.g.g. Uregulowania zawarte $\mathrm{w}$ przytoczonych przepisach wprowadzają dwa odmienne modele odpowiedzialności za szkody górnicze restytucyjny oraz prewencyjny. Istotą funkcji restytucyjnej jest naprawienie wyrządzonej szkody, zaś prewencyjnej ograniczenie jej skutków bądź częściowe lub całkowite jej zapobieżenie. Pierwszy z przytoczonych wyżej przepisów określa model restytucyjny. Wskazuje na to bezsprzecznie wykładnia literalna wyrażenia „żądać naprawienia wyrządzonej tym ruchem szkody”.

Drugi z modeli odpowiedzialności za szkody górnicze ustawodawca zawarł w art. 150 i 152 u.p.g.g. Na funkcję prewencyjną wskazuje przede wszystkim treść pierwszego z wymienionych, zgodnie z którym przepisy o naprawianiu szkód określonych działem VIII u.p.g.g. stosuje się odpowiednio do zapobiegania tym szkodom. Artykuł 152 ust. 1 u.p.g.g. reguluje natomiast uprawnienia sądu do nakazania niezwłocznej wypłaty odpowiedniej kwoty pieniężnej poszkodowanemu celem natychmiastowego zapobieżenia szkodzie lub jej dalszym skutkom.

Analiza funkcji roszczeń z art. 144 i 150 u.p.g.g. oraz związanych z nimi modelami odpowiedzialności nasuwa wątpliwość, która wymaga dokładniejszego zbadania. Należy zwrócić uwagę, jak już wskazano w pkt 3 dotyczącym legitymacji

14 T. j. Dz.U. z 1994, Nr 27, poz. 96 ze zm., uchylony 1 stycznia 2012 roku.

15 Szerzej na temat wątpliwości dotyczących definicji legalnej ruchu zakładu górniczego zob.: R. Mikosz, Odpowiedzialność za szkody wyrządzone ruchem zakładu górniczego, Katowice 2006, s. 93 i nast. 
czynnej, na brak możliwości sprzeciwu właściciela przeciwko zagrożeniom spowodowanym ruchem zakładu górniczego, który jest zgodny z ustawą. Legislator w zamian przyznaje jednak właścicielowi roszczenie o naprawienie szkody wyrządzonej tym ruchem. Istotne jest jednak to, jak przytoczona regulacja odnosi się do uprawnień wynikających z art. 150 u.p.g.g., który - jako dający możliwość zapobiegania szkodom - jest bezsprzecznie formą sprzeciwu wobec zagrożeń spowodowanych ruchem zakładu górniczego. Skoro ustawodawca wyłączył taką możliwość w art. 144 u.p.g.g., to czy w ślad za tą regulacją właściciel może skorzystać ze sposobności zapobieżenia szkodzie bądź jej ograniczeniu? Odpowiedź na postawione pytanie nie jest jednoznaczna, zależy od tego, czy ruch zakładu górniczego prowadzony jest zgodnie z ustawą, czy też nie. Jak już podkreślano wyżej, bezsporny jest fakt, że możliwość zapobiegania szkodom należy zakwalifikować jako formę kontestacji. Z uwagi na to niemożność sprzeciwu wobec zagrożeń spowodowanych ruchem zakładu górniczego, którego ruch jest zgodny z ustawą, wyłącza możliwość skorzystania przez właściciela z przysługujących mu roszczeń o charakterze prewencyjnym zawartych $\mathrm{w}$ art. 150 u.p.g.g. A contrario należy więc stwierdzić, że z uprawnienia dającego możliwość zapobieżenia szkodzie właściciel będzie mógł skorzystać jedynie w sytuacji, gdy ruch zakładu górniczego jest prowadzony niezgodnie z ustawą. Oczywiście z uwagi na istotę prawa własności, w szczególności w odniesieniu do dóbr niematerialnych, ograniczenie możliwości ochrony przed zagrożeniami spowodowanymi ruchem zakładu górniczego nie będzie miało zastosowania ${ }^{16}$.

16 Szerzej na ten temat zob.: R. Mikosz, op. cit., s. 75 i nast. Należy zaznaczyć, że pogląd wyrażony we wskazanym opracowaniu na gruncie poprzednio obowiązującej u.p.g.g. zachowuje swoją aktualność w obecnie obowiązującym stanie prawnym. 


\section{SPOSOBY NAPRAWIENIA SZKODY}

Już na wstępie należy zwrócić uwagę, że przepisy prawa geologicznego i górniczego nie wprowadzają żadnych modyfikacji w zakresie dotyczącym sposobów naprawienia szkody przewidzianych w k.c. Formy naprawienia szkody przysługujące poszkodowanemu zostały zawarte $\mathrm{w}$ art. 363 k.c. Zgodnie z tym unormowaniem owa restytucja może przybrać postać przywrócenia stanu poprzedniego, bądź zapłaty odpowiedniej sumy pieniężnej. Ustawodawca wskazuje jednak, że gdy przywrócenie stanu poprzedniego jest niemożliwe lub pociąga dla zobowiązanego nadmierne trudności lub koszty, roszczenie poszkodowanego ogranicza się do świadczenia w pieniądzu. Nie można jednak pozostawić bez komentarza art. 147 ust. 1 u.p.g.g., w którym ustawodawca poprzez zwrot „przywrócenie stanu poprzedniego może w szczególności nastąpić przez [...]" wskazuje preferowaną formę restytucji. Nie znając regulacji zawartej w art. 363 k.c., można twierdzić, że poszkodowanemu nie przysługuje prawo wyboru pomiędzy roszczeniem o zapłatę odpowiedniej sumy pieniężnej, a przywróceniem stanu poprzedniego. Przedmiotowa teza byłaby jednak błędna z uwagi na treść przytoczonego wyżej art. 145 u.p.g.g., w zw. ze wspomnianym art. 363 k.c.

Przywrócenie stanu poprzedniego zgodnie z regulacją zawartą w art. 147 u.p.g.g. może nastąpić w szczególności przez dostarczenie: gruntów, obiektów budowlanych, urządzeń, lokali, wody lub innych dóbr tego samego rodzaju. Warto wskazać, że w praktyce stosowanie niniejszego przepisu polega przede wszystkim na prostowaniu budynków (tzw. rektyfikacji) czy naprawie uszkodzeń wewnętrznych. Jak słusznie wskazuje B. Rakoczy ${ }^{17}$, przytoczony rozszerzony zakres możliwości restytucyjnych jest przez legislatora sformułowany w sposób nieprecyzyjny. Z uwagi na treść prawa własności i unormowań k.c. nie

17 B. Rakoczy, Odpowiedzialność za szkody wyrządzone ruchem zakładu górniczego, w: Prawna regulacja geologii i górnictwa w Polsce, Czechach i na Słowacji. Wybrane zagadnienia, red. G. Dobrowolski, G. Radecki, Katowice 2014, s. 221 i nast. 
można przecież w kontekście gruntów, urządzeń czy obiektów budowlanych używać zwrotu „dostarczyć”. Przepis ten powinien jasno wskazywać, że - $\mathrm{w}$ odniesieniu do wspomnianych rzeczy - formą przywrócenia stanu poprzedniego może być zawarcie umowy, której treścią jest przeniesienie własności. Użyty przez ustawodawcę czasownik wydaje się prawidłowy jedynie w odniesieniu do wody lub tożsamych dóbr.

Kolejną różnicą pomiędzy regulacjami k.c. a przepisami prawa geologicznego i górniczego, odnoszącą się do naprawienia szkody, jest termin przedawnienia roszczeń. Ustawodawca w art. 442 k.c. daje poszkodowanemu czynem niedozwolonym możliwość wystąpienia z roszczeniem w okresie trzech lat od dnia, w którym dowiedział się o szkodzie i o osobie zobowiązanej do jej naprawienia. Termin ten jednak nie może być dłuższy niż dziesięć lat od dnia, w którym nastąpiło zdarzenie wywołujące szkodę. Artykuł 149 u.p.g.g., zgodnie z którym roszczenia o naprawienie szkody spowodowanej ruchem zakładu górniczego przedawniają się z upływem lat 5 od dowiedzenia się o tej szkodzie, stanowi jednak przepis szczególny w odniesieniu do przytoczonej regulacji k.c. Należy wskazać, że motywacją legislatora do wprowadzenia przepisu wydłużającego okres przedawnienia była przede wszystkim specyfika szkód górniczych, które mogą się ujawnić dopiero parę czy nawet paręnaście lat po zdarzeniu leżącym u podłoża przedmiotowego uszczerbku.

\section{POSTĘPOWANIE UGODOWE}

Pierwszym a zarazem obligatoryjnym etapem dochodzenia roszczeń z tytułu szkód spowodowanych ruchem zakładu górniczego jest postępowanie ugodowe. W ślad za treścią art. 151 u.p.g.g. dopiero po wyczerpaniu przedmiotowego postępowania możliwe jest dochodzenie roszczeń na drodze sądowej. Niewyczerpanie postępowania ugodowego, zgodnie z art. 199 kodeksu postępowania cywilnego ${ }^{18}$, będzie skutkować odrzuce-

18 T. j. Dz.U. z 2014 roku, poz. 101 ze zm. (dalej cyt.: k.p.c.). 
niem pozwu przed sąd. Należy jednak wskazać, że konieczność przeprowadzenia postępowania ugodowego nie jest pionierskim zabiegiem ustawodawcy, podobna regulacja obowiązywała już na gruncie poprzedniej ustawy ${ }^{19}$. U podłoża takiej regulacji leżą przede wszystkim przesłanki odpowiedzialności i możliwości obrony przedsiębiorcy prowadzącego ruch zakładu górniczego. Podmiot ten wiedząc, że szanse na uchylenie się od odpowiedzialności są znikome, często nie kwestionuje roszczeń, a jedynie usiłuje obniżyć ich wartość. Kolejnym powodem wprowadzenia obligatoryjnego postępowania ugodowego była zapewne przewlekłość postępowań tego typu prowadzonych przed sądami powszechnymi oraz ich wysokie koszty obciążające przedsiębiorcę, wiążące się z wysoką wartością przedmiotu sporu oraz koniecznością powoływania biegłych różnych specjalności.

Artykuł 151 ust. 1 u.p.g.g. wskazuje, że warunek wyczerpania postępowania ugodowego należy uznać za spełniony, jeżeli przedsiębiorca odmówił zawarcia ugody lub jeżeli od skierowania przez poszkodowanego roszczenia wobec przedsiębiorcy upłynęło 30 dni, chyba że poszkodowany, zgłaszając żądanie zawarcia ugody, wyznaczył dłuższy termin. Ugoda zawarta w formie aktu notarialnego stanowi zgodnie $\mathrm{z}$ art. 151 ust. 2 u.p.g.g. tytuł egzekucyjny w rozumieniu przepisów k.p.c.

Dotychczasowa praktyka wskazuje, że w większości przypadków poszkodowani oraz przedsiębiorący prowadzący ruch zakładu górniczego zawierają ugodę bez konieczności kierowania sprawy na drogę postępowania sądowego. W przypadku największej spółki górniczej w Europie tj.: Kompanii Węglowej tym sposobem rozstrzygane jest nawet 96\% wszystkich sporów $^{20}$. Korzyści płynące dla przedsiębiorcy prowadzącego ruch zakładu górniczego z ugodowego rozstrzygania sporów były impulsem dla przedsiębiorstw do wprowadzenia przepisów wewnętrznych normujących zasady i tryb postępowania w sprawach szkód górniczych. Przepisy te nie mają oczywiście cha-

19 T. j. Dz.U. z 1994 roku, nr 27, poz. 96 ze zm. (dalej cyt.: d.u.p.g.g.).

20 Źródło:https://www.kwsa.pl/pozostala_dzialalnosc/likwidacja_szkod/ zasady_i_tryb_postepowania [dostęp: 31 sierpnia 2015 r.]. 
rakteru normatywnego, jednakże ich analiza za pośrednictwem witryn internetowych najważniejszych na polskim rynku spółek górniczych (tj.: Kompania Węglowa S.A., Jastrzębska Spółka Węglowa S.A., Katowicki Holding Węglowy S.A. oraz Lubelski Węgiel „BOGDANKA” S.A.) ${ }^{21}$ prowadzi do wniosku, że są one niemalże tożsame.

Pozasądowe postępowanie ugodowe rozpoczyna się na pisemny wniosek poszkodowanego, za wyjątkiem tzw. sytuacji awaryjnych oraz w razie wystąpienia wstrząsu pochodzenia górniczego, w przypadku których zgłoszenia można dokonać telefonicznie. Jeśli chodzi o spółki górnicze, na które składa się kilka oddziałów (zakładów górniczych), zgłoszenie należy złożyć w zakładzie właściwym miejscowo ze względu na miejsce wystąpienia szkody. W razie wątpliwości na przytoczonych witrynach zamieszczone zostały mapy obrazujące przebieg granic terenów górniczych poszczególnych oddziałów. Do szkód w gruntach i uprawach odnosi się szczególna regulacja, zgodnie z którą w takim przypadku wniosek winien zostać złożony nie później niż 14 dni przed datą planowanego zbioru. Następnie w przypadku stwierdzenia związku przyczynowego pomiędzy szkodą i ruchem zakładu górniczego przeprowadzane są oględziny szkody, z propozycją których występuje zakład górniczy w terminie 14 dni od otrzymania wniosku. Czynność ta zakończona jest protokołem, w którym szczegółowo opisuje się powstałe uszkodzenia. W sytuacji, gdy stanowiska stron są zgodne następuje zawarcie ugody, która jest podstawą do naprawienia szkody. Należy wskazać, że w przypadku restytucji polegającej na przywróceniu stanu poprzedniego, naprawa może być wykonana zarówno przez poszkodowanego, jak i przez zakład górniczy - zależnie od treści ugody. Drugi z przytoczonych

21 Zob. 1) źródło: https://www.kwsa.pl/pozostala_dzialalnosc/likwidacja_szkod/zasady_i_tryb_postepowania_dostęp: 1 września 2015 r.]; 2) https://www.jsw.pl/odpowiedzialny-biznes/szkody-gornicze/tryb-postepowania/ [dostęp: 1 września 2015 r.]; 3) http://www.khw.pl/firma/Tryb postepowania.html [dostęp: 1 września 2015 r.]; 4) http://www.lw.com.pl/ pl,2,s409,zasady_i_tryb_postepowania.html [dostęp: 1 września 2015 r.]. 
przypadków wymaga jednak przeprowadzenia postępowania przetargowego.

Opisany tryb pozasądowego postępowania ugodowego jest korzystny nie tylko dla przedsiębiorcy, ale również dla samego poszkodowanego, przede wszystkim z uwagi na możliwość uniknięcia przewlekłego i kosztownego postępowania sądowego. Istotą ugody są oczywiście wzajemne ustępstwa stron, co w rezultacie może skutkować niższym odszkodowaniem dla poszkodowanego. Nie należy zapominać jednak, że wielu poszkodowanych, zdając sobie sprawę z długotrwałości postępowania sądowego, dobrowolnie obniża swoje roszczenia, chcąc tym samym skłonić przedsiębiorcę prowadzącego ruch zakładu górniczego do zawarcia ugody celem szybszego naprawienia powstałej szkody. Polubowne zakończenie sprawy wyłącza konieczność kierowania jej na drogę postępowania sądowego, nie zamyka jednak możliwości wniesienia powództwa w przypadku powstania dalszych szkód w przyszłości.

\section{KWESTIE PROCEDURALNE}

Brak rozstrzygnięcia sporu na drodze postępowania ugodowego, skutkuje koniecznością skierowania powództwa do właściwego sądu powszechnego. Należy wskazać, że postępowanie będzie prowadzone w oparciu o przepisy k.p.c. Artykuł $187 \S 1$ pkt 1 k.p.c. wskazuje, że obligatoryjnym elementem wniesionego powództwa w sprawach o prawa majątkowe jest oznaczanie wartości przedmiotu sporu. W sprawach, których przedmiotem jest roszczenie o naprawienie szkody spowodowanej ruchem zakładu górniczego określenie wartości przedmiotu sporu uzależnione jest od formy restytucji. Będzie to koszt przywrócenia stanu poprzedniego oparty na zleconej przez powoda opinii prywatnej bądź też jego własnych wyliczeniach. Natomiast w przypadku roszczenia odszkodowawczego, wartością przedmiotu sporu będzie samodzielnie określana wysokości roszczenia przez powoda. 
Istotną regulacją dla podmiotu występującego z roszczeniem o naprawienie szkody spowodowanej ruchem zakładu górniczego jest art. 96 ust. 1 pkt 12 ustawy o kosztach sądowych w sprawach cywilnych ${ }^{22}$. Zgodnie z tym przepisem strona dochodząca naprawienia szkód spowodowanych ruchem zakładu górniczego, o których mowa w dziale VIII u.p.g.g., nie ma obowiązku uiszczania kosztów sądowych.

Należy zaznaczyć, że zawyżanie wartości przedmiotu sporu, będące $\mathrm{w}$ istocie próbą wyegzekwowania wyższego odszkodowania, nie leży w interesie powoda. Jest to spowodowane kosztami, które powód będzie zobligowany ponieść, w sytuacji gdy Sąd wyrokiem zasądzi jedynie część żądanej w pozwie kwoty.

\subsection{CZYNNA LEGITYMACJA PROCESOWA}

Zagadnienie czynnej legitymacji procesowej jest bezpośrednio związane z art. 144 u.p.g.g. Wskazany przepis zakłada istnienie stron, których interesy są w oczywisty sposób przeciwstawne. Jak słusznie wskazuje B. Rakoczy ${ }^{23}$, z jednej strony ustawodawca dopuszcza ruch zakładu górniczego, kierując się głównie względami gospodarczymi, związanymi z funkcjonowaniem takiego zakładu i pozyskiwaniem kopalin. Z drugiej jednak strony z góry zakłada, że ruch ten z dużym prawdopodobieństwem wywoła określony uszczerbek na dobrach chronionych prawem.

Zgodnie z art. 144 ust. 1 u.p.g.g. pierwszą grupę podmiotów posiadających legitymację czynną do dochodzenia roszczeń tytułem szkód powstałych na skutek ruchu zakładu górniczego tworzą właściciele dóbr chronionych prawem. Bez wątpienia przedmiotowym dobrem może być zarówno ruchomość, jak i nieruchomość. Praktyka wskazuje jednak, że roszczenie to w głównej mierze przysługiwać będzie właścicielom nieruchomości. W przytoczonym przepisie ustawodawca zakłada a priori,

22 T. j. Dz.U. z 2014 roku, poz. 1025 ze zm.

23 B. Rakoczy, op. cit. 
że właściciel nie może sprzeciwić się zagrożeniom spowodowanym ruchem zakładu górniczego, który jest zgodny z ustawą. Taka konstrukcja nie pozostawia wyboru poszkodowanemu, który jest zmuszony „pogodzić” się z faktem wystąpienia szkody, a następnie wystąpić z roszczeniem. Należy stwierdzić więc, że ustawodawca z rozmysłem skonstruował przepis, który directe formułuje uprawnienia poszkodowanego, nie odwołując się w tej kwestii do k.c. z uwagi na brak możliwości wyrażenia sprzeciwu co do zagrożenia spowodowanego ruchem zakładu górniczego. W razie braku przytoczonej regulacji lex specialis poszkodowany, w celu ochrony przysługującego mu prawa własności, mógłby wystąpić z roszczeniem negatoryjnym zawartym w art. 222 § 2 k.c., żądając, obok przywrócenia stanu zgodnego $\mathrm{z}$ prawem, także zaniechania naruszeń.

Artykuł 144 ust. 2 u.p.g.g. wskazuje na drugą grupę podmiotów, którym przysługuje możliwość dochodzenia roszczeń na gruncie przepisów tejże ustawy, są to podmioty inne niż właściciel, których prawa majątkowe są zagrożone ruchem zakładu górniczego. W stosunku do przytoczonego wyżej ustępu 1 regulacja ta ma charakter znacznie szerszy. Zakłada bowiem istnienie zagrożenia jakiegokolwiek prawa majątkowego, które to zagrożenie spowodowane zostało ruchem zakładu górniczego. Kluczowe znacznie ma więc związek przyczynowy pomiędzy zagrożeniem prawa majątkowego a ruchem zakładu górniczego. W ustawie próżno szukać uregulowania dotyczącego kwestii związku przyczynowego, stąd należy sięgnąć do zasady ogólnej określonej w art. 361 k.c. Zgodnie z tym unormowaniem zobowiązany do odszkodowania ponosi odpowiedzialność tylko za normalne następstwa działania lub zaniechania, z którego szkoda wynikła.

Ostatnią grupę podmiotów posiadającą czynną legitymację tworzą te nieujęte w dwóch poprzednich. Rozwiązanie takie wskazuje wprost treść art. 144 ust. 3 u.p.g.g. Podmioty te mogą dochodzić roszczeń z tytułu szkody spowodowanej ruchem zakładu górniczego jednakże na podstawie zasad ogólnych określonych w k.c. ${ }^{24}$

24 Szerzej na ten temat zob. W. Czachórski, A. Brzozowski, M. Safjan, E. Skowrońska-Bocian, op. cit., s. 258. 


\subsection{BIERNA LEGITYMACJA PROCESOWA}

Katalog podmiotów odpowiedzialnych na zasadzie ryzyka za szkody powstałe na skutek ruchu zakładu górniczego został przez ustawodawcę zawarty w art. 146 ust. 1-4 u.p.g.g. Co do zasady odpowiedzialność ponosi przedsiębiorca prowadzący ruch zakładu górniczego. W ust. 2-4 przytoczonego przepisu ustawodawca rozszerzył katalog podmiotów przeciwko którym można skierować roszczenia, określając je w następujący sposób:

1) inne podmioty prowadzące działalność regulowaną u.p.g.g., nawet jeśli nie stosuje się do nich przepisów dotyczących ruchu zakładu górniczego;

2) w przypadku niemożności ustalenia kto wyrządził szkodę odpowiada przedsiębiorca, który w dniu ujawnienia się szkody miał prawo prowadzić w obszarze górniczym, w granicach którego wystąpiła szkoda, działalność regulowaną u.p.g.g.;

3) jeśli nie istnieje przedsiębiorca odpowiedzialny za szkodę ani jego następca prawny, za szkodę odpowiedzialny będzie Skarb Państwa, którego reprezentować będzie właściwy organ nadzoru górniczego na zasadach określonych w dziale VIII u.p.g.g.

Nadto należy zwrócić uwagę na ust. 5 i 6 art. 146 u.p.g.g. W pierwszym z nich ustawodawca wprowadza odpowiedzialność solidarną wyżej wskazanych podmiotów oraz innych podmiotów, jeśli szkoda nastąpiła także z innych przyczyn niż ruch zakładu górniczego. Natomiast w drugim ze wskazanych przepisów określa solidarną odpowiedzialność przedsiębiorcy oraz podmiotów zawodowo trudniących się wykonywaniem powierzonych przez tego przedsiębiorcę czynności.

W efekcie, na skutek wprowadzonego unormowania, nie może dojść do sytuacji, w której brak będzie podmiotu odpowiedzialnego za szkody powstałe na skutek ruchu zakładu górniczego. Wydaje się, że jest to główny powód obszernego charakteru opisanego wyżej katalogu podmiotów, jednak niejedyny. Jako kolejny należy wspomnieć poruszaną już wyżej kwestię niemożności sprzeciwu zagrożeniom spowodowanym ruchem zakładu 
górniczego oraz zagrożenie ruchem zakładu górniczego praw majątkowych.

Co więcej, jak słusznie zauważa B. Rakoczy ${ }^{25}$, legitymacja bierna podmiotów wskazanych w pkt 2 i 3 jest jedynie formalna, gdyż nie są sprawcami szkody. Odpowiedzialność pierwszego z nich powstaje na skutek obiektywnej niemożności ustalenia podmiotu, który wyrządził szkodę. Natomiast Skarb Państwa, wskazany w pkt 3, będzie odpowiadał w ostateczności, tj. w razie nieistnienia podmiotu odpowiedzialnego za szkodę i jego następcy prawnego. Nadto, w przeciwieństwie do podmiotu z pkt 2, który może wykazać brak legitymacji biernej, wskazując na sprawcę szkody, odpowiedzialność Skarbu Państwa w przypadku spełnienia opisanej przesłanki jest nieuchronna. Nie zależy bowiem ani od istnienia związku pomiędzy szkodą czy przedsiębiorcą a Skarbem Państwa, ani także od tego czy Skarb Państwa miał wpływ na działania przedsiębiorcy. Nieistotny pozostaje również fakt wydania odpowiedniej decyzji zezwalającej przedsiębiorcy prowadzić ruch zakładu górniczego. Kształt opisanej regulacji ma swoje źródło w specyfice szkód górniczych, które - jak już wskazano w pkt 4 - mogą się ujawnić dopiero po paru czy też parunastu latach, co w przypadku odmiennej regulacji mogłoby skutkować nieistnieniem podmiotu legitymowanego biernie, a w konsekwencji niemożnością uzyskania odszkodowania.

\section{ANALIZA WYBRANYCH ORZECZEŃ SĄDU NAJWYŻSZEGO}

Zajmując się tematyką szkód górniczych, nie sposób nie przytoczyć istotnych na tle omawianych regulacji orzeczeń Sądu Najwyższego, wskazujących praktyczne ich stosowanie.

Pierwsze z dwóch orzeczeń, które należy poddać analizie związane jest z legitymacją czynną opisaną w pkt 3 niniejszego artykułu. Z literalnego brzmienia art. 144 ust. 1 u.p.g.g. wydaje się, że roszczenie o naprawienie szkody przysługuje każdocze-

25 B. Rakoczy, op. cit., s. 221 i nast. 
snemu właścicielowi dobra chronionego prawem. Zapatrywanie Sądu Najwyższego jest jednak zgoła inne. W wyroku z dnia 14 kwietnia 1971 roku (sygn. akt. III CRN 56/71)26 Sąd Najwyższy uznał, że art. 548 k.c. odnosi się do tych tylko ciężarów i korzyści, jakie powstały po wydaniu rzeczy. Gdy tymczasem w sprawie chodzi o odszkodowanie dotyczące zbytej nieruchomości przypadające za okres wcześniejszy, mogłoby ono przejść na nabywcę tylko na podstawie szczególnej umowy.

Zgodnie z tą tezą odszkodowanie przysługuje poszkodowanemu, którym jest właściciel nieruchomości w chwili powstania szkód górniczych. Mimo wielokrotnych zmian stanu prawnego od wydania przytoczonego orzeczenia, zachowuje ono jednak swoją ważność na gruncie ustawy Prawo geologiczne i górnicze. Takie zapatrywanie Sądu Najwyższego na przedmiotową kwestię niesie niekorzystne konsekwencje dla nowego właściciela dobra chronionego prawem. Jeśli następca prawny wystąpi z roszczeniem tytułem szkód spowodowanych ruchem zakładu górniczego i je uzyska, to dotychczasowy właściciel będzie posiadał legitymację czynną do wystąpienia z powództwem o zwrot przedmiotowego odszkodowania na podstawie przepisów o bezpodstawnym wzbogaceniu. Takie stanowisko jest zgodne z regulacjami k.c., gdyż nowy właściciel nie jest podmiotem poszkodowanym, stąd przyznana mu restytucja jest świadczeniem nienależnym. Nowy właściciel będzie legitymowany czynnie do dochodzenia roszczeń jedynie w sytuacji, gdy szkody górnicze powstały po uzyskaniu przez niego tytułu prawnego w postaci prawa własności do chronionego dobra.

Rozwiązaniem opisanego problemu nabywcy jest wskazana przez Sąd Najwyższy możliwość zawarcia „szczególnej umowy". Treścią przedmiotowej umowy byłaby cesja na nabywcę przysługujących dotychczasowemu właścicielowi roszczeń o naprawienie szkód górniczych powstałych przed datą zbycia nieruchomości.

Drugie orzeczenie dotyczy roszczenia odszkodowawczego wniesionego po wejściu w życie obowiązującej ustawy Prawo

26 Zob. wyrok Sądu Najwyższego z dnia 14 kwietnia 1971 roku (sygn. akt: III CRN 56/71). 
geologiczne i górnicze, tj.: po 1 stycznia 2012 roku, za szkody górnicze powstałe na gruncie poprzednio obowiązującej u.p.g.g. W uchwale z dnia 22 listopada 2013 roku (sygn. akt. III CZP 75/13) ${ }^{27}$ Sąd Najwyższy uznał, że w opisanej sytuacji stosować należy przepisy d.u.p.g.g. Ustawa ta była dla poszkodowanego jednak znacznie mniej korzystna, przede wszystkim z uwagi na regulację zawartą $\mathrm{w}$ art. 94. Zgodnie $\mathrm{z}$ tym unormowaniem roszczenie o zapłatę odszkodowania pieniężnego przysługiwało poszkodowanemu dopiero w sytuacji, gdy restytucja naturalna była niemożliwa czy też nadmiernie kosztowna ${ }^{28}$. Wydaje się, że stanowisko Sądu Najwyższego w przedmiotowej sprawie jest słuszne i czyni zadość przepisom prawa intertemporalnego.

\section{PODSUMOWANIE}

Podsumowując rozważania na przedmiotowy temat, należy przede wszystkim uznać część przepisów zawartych w dziale VII u.p.g.g. za nazbyt lapidarne i nieprecyzyjne ${ }^{29}$. Nie sposób nie dostrzec, że - z uwagi na obszar występowania szkód górniczych oraz spowodowanych nimi uszczerbków - ustawodawca wzmacnia ochronę właścicieli i innych podmiotów, których dobra są zagrożone. Łagodząc przesłanki odpowiedzialności odszkodowawczej, znacznie ogranicza możliwość uchylenia się od odpowiedzialności przez przedsiębiorców prowadzących ruch zakładu górniczego. Co więcej, rozszerza katalog podmiotów biernie legitymowanych, przyznaje możliwość wystąpienia z roszczeniami o charakterze prewencyjnym oraz wydłuża okres przedawnienia. Najwięcej zastrzeżeń budzi jednak prawo wyboru formy restytucji, które nie występowało na gruncie poprzednio obowiązującej ustawy.

27 Zob. uchwała Sądu Najwyższego z dnia 22 listopada 2013 roku (sygn. Akt: III CZP 75/13).

28 Zob. wyrok Sądu Apelacyjnego w Katowicach z dnia 9 lipca 2013 roku (sygn. akt: V ACa 229/13).

29 Patrz np.: pkt 6. 
Nie ulega wątpliwości, że branża górnicza przed wejściem w życie ustawy Prawo geologiczne i górnicze miała znaczny udział w dochodach Skarbu Państwa. Ustawodawca nie przewidział jednak swoistego „krachu”, który dokonał się w ostatnich latach, przede wszystkim w gałęzi odpowiedzialnej za wydobycie węgla kamiennego. Należy się więc zastanowić, czy na skutek dokonanych procesów restrukturyzacyjnych, spadku rentowności zakładów górniczych oraz coraz większego udziału kapitału zagranicznego, kształt obecnej regulacji nie powinien ulec zmianie w kierunku liberalizacji na korzyść przedsiębiorców prowadzących ruch zakładu górniczego.

\section{BIBLIOGRAFIA}

Agopszowicz A., Odpowiedzialność za szkody wyrządzone robotami górniczymi, Warszawa 1964.

Czachórski W., Brzozowski A., Safjan M., Skowrońska-Bocian E., Zobowiazania. Zarys wykładu, Warszawa 2009.

Lipińska K., Tryb dochodzenia roszczeń z tytułu tzw. Szkód górniczych, w: Prawna regulacja geologii i górnictwa $w$ Polsce, Czechach $i$ na Stowacji. Wybrane zagadnienia, red. G. Dobrowolski, G. Radecki, Katowice 2014.

Malewski J., Szkody $w$ środowisku, odszkodowania i zabezpieczenia roszczeń na terenach górnictwa odkrywkowego, Wrocław 2007.

Mikosz R., Odpowiedzialność za szkody wyrzadzone ruchem zakładu górniczego, Katowice 2006.

Rakoczy B., Odpowiedzialność za szkody wyrzadzone ruchem zakładu górniczego, w: Prawna regulacja geologii i górnictwa $w$ Polsce, Czechach i na Stowacji. Wybrane zagadnienia, pod red. G. Dobrowolski, G. Radecki, Katowice 2014.

Kontakt e-mail:

p.relidzynski@gmail.com 